\title{
Relationship between Degree of Risk, Cost and Level of Compliance to Occupational Health and Safety Regulations in Construction
}

Abimbola Windapo (University of Cape Town, South Africa)

\begin{abstract}
This paper investigates the role of statutory health and safety (H\&S) regulations in managing construction project risks. The study examines whether the decision made by contractors to comply with the regulations, the cost of compliance and savings of $\mathrm{H} \& \mathrm{~S}$ regulatory requirements is influenced by the degree or level of risk, which the regulations are trying to prevent. The rationale for the examination stems from previous studies which establish that building designers and contractors perceive the cost of complying with regulations as additional burdens, which they have to conform to, and which are in some cases unnecessary, and also the fact that construction related injuries and fatalities are on the increase. Qualitative and quantitative data obtained from a descriptive survey and H\&S site audit by the Master Builder Association of the Western Cape (MBAWC) were used as the measurements of risk, level of compliance to regulations, cost of compliance and savings. By correlating the quantitative and qualitative data, there is empirical evidence to support a negative relationship between the degree of risk, level and cost of compliance and cost savings. Based on the study's findings, this paper concludes that the decision made by contractors to comply with $\mathrm{H} \& \mathrm{~S}$ regulatory requirements is influenced by the perceived cost saving on account of compliance and that cost savings are influenced by the probability of accident occurrence which is an element of the degree of risk which the regulation is trying to prevent or control.
\end{abstract}

Keywords: Accident, Cost, Health and Safety, Regulations and Risk

\section{Introduction}

Construction industries worldwide are notorious for unacceptably high accident and fatality rates, both of which were noted by Ulang et al. (2010), Sidumedi (2009) and Health and Safety Executive (HSE) (2004) in comparison to other industries. According to Odeyinka et al. (2005), construction workers are six times more likely to be killed at work than those in other industries. In South Africa, construction industry records show that work related deaths, occupational diseases and injury claims absorb a significant proportion of the Gross National Product (Benjamin and Greef 1997) even though there are concerns that the reports in South Africa fail to capture the full number of accidents (van Huyssteen et al. 2009; and Sidumedi 2009). Warwick (2011), Baxendale and Owain (2000), and Coble et al. (2000) attribute accidents and fatalities associated with and reported in the construction industry to non-compliance by contractors with H\&S regulations on construction sites.

Regulations are intended to address and satisfy the public mandate for managing the risks and benefits of technology (Wolski, et al. 2000), designed to improve the performance of individual and organizational behaviour in ways that reduces social harms (Coglianese, et al. 2003), and stimulates the building designer and contractor to follow strict sets of rules with regard to the way in which structures are built (HSE 2004). However, in instances of poor quality housing a high number of accidents and fatalities (Construction Industry Development Board (cidb) 2009a), building failure (Ayininuola and Olalusi 2004), failed or unfinished construction projects, which are common in the construction industry, suggest that construction industry stakeholders are not complying with regulatory requirements 
(Warwick 2011; Baxendale and Owain 2000; and Coble et al. 2000). The reasons for lack of compliance include regulatory authorities imposing regulations that are in practice unattainable or prohibitively expensive (Williams 1995); building designers and contractors viewing regulations as additional burdens with which they have to comply (Gann et al. 1998) and that while regulations only apply in some cases, the extra precautions are considered an unnecessary cost (Emrath 2011).

While Weil (2001) questions whether the standards complied with by contractors are linked with the underlying physical hazards and cost of accidents (CoA), or whether the H\&S standards most cited by government regulation bodies diverge from the major sources of fatalities and injuries on construction projects. McConnaughey (1978) in a previous study maintains that the level of safety or performance outcomes which a regulation is intended to provide, and thus the resulting costs and benefits derived from its implementation, relates to the degree or level of risk which the regulation attempts to prevent or control.

These arguments by Weil (2001), Gann et al. (1998), Williams (1995), McConnaughey (1978) and the fact that it is not known whether one of the contributing factors to the escalating number of site accidents is that too much attention is placed by construction site management on lower risk activities and operations instead of on the activities that have the potential to cause the most injuries, form the basis for this study. The objective of this paper is therefore to fill the knowledge gap and to establish whether there is a relationship between the degree of risk which the regulation attempts to prevent/control, the level of compliance with the OHSA regulatory requirements, the cost of compliance/implementation and cost savings when the OHSA requirements are complied with.

The research framework for this study is shown in Figure 1. Before these correlates are determined and discussed, the paper will first of all review the concept of OHSA regulations, the measurement of construction risks, the level of compliance, and costs and benefits of compliance to OHSA regulations.

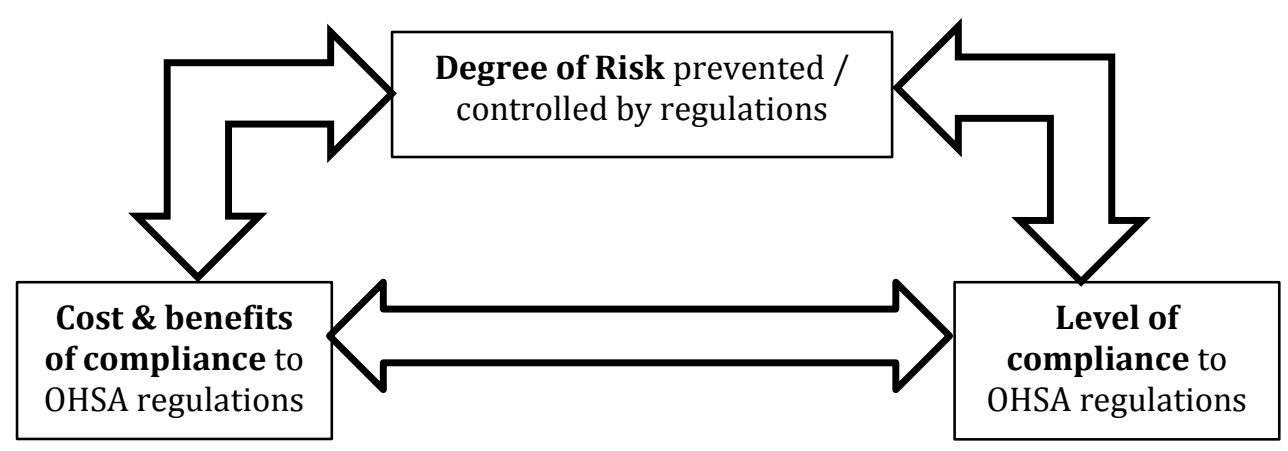

Figure 1 Research framework

\section{Concept of Regulations}

The state is a potential resource or threat to every industry in the society, the construction industry being no exception (Stigler 1971). The state establishes technical standards, permits construction activities and enforces state regulations (Winch and Campagnac 1995; and Ang et al. 2005). The government regulations are the outcome of legal efforts, strongly influenced by governmental and social forces, evaluated against the consequences of the process and are often enacted to reduce the probability of negative performance outcomes in terms of quality, health and safety issues on construction projects. Regulations come in many forms and can be imposed by government at different levels (Emrath 2011) for the 
reason that people habitually look to government to take the lead in creating a scheme of prevention, protection and control (Spence 2004).

\section{Overview of OHSA Regulations in South Africa}

According to cidb (2009a), the activities in the construction industry due to its poor H\&S performance record are the subject of various legislative and institutional frameworks in South Africa of which the primary objective is the prevention of accidents and their consequences in terms of injury, disablement, fatality and ill health within the work environment. The cidb report notes that South Africa is not lacking in terms of H\&S legislation and that South Africa's legislative framework addresses H\&S at three levels firstly in terms of the national constitution, then in terms of Acts such as the Occupational Health and Safety Act No. 85 of 1993 (OH\&S Act), and the complementary Compensation for Occupational Injuries and Diseases Act No 130 of 1993 (COID Act). These are followed by a range of regulations promulgated under OHSA, in particular the Construction Regulations promulgated in July 2003. Although it cannot be quantified, cidb (2009a) alleges that the Construction Regulations have had a positive impact on reducing H\&S accidents.

The OHSA No. 85 of 1993 of South Africa stipulates the steps to be taken in order to ensure a safe and healthy work environment for all employees on a construction site (Hermanus, 2001) and contractors are obliged to comply with the requirements of the Act. However, Windapo (2011), Bettesworth (2011), MBAWC (2011) and cidb (2009a) noted that building contractors in South Africa do not comply fully with $\mathrm{H} \& \mathrm{~S}$ regulations, and that even though $\mathrm{H} \& \mathrm{~S}$ issues have seen some improvement over the years, the numbers of people that get injured or die on construction sites in South Africa is still high (Department of Labour (DoL) 2007; and cidb, 2009b).

\section{Level of Compliance to OHSA Regulatory Requirements on Construction Sites}

Weil (2001) notes that the H\&S standards cited most frequently diverge from the major sources of fatalities and injuries on construction projects and that it is not known if the standards frequently complied with are linked with underlying physical hazards, and are in turn associated with injuries and illnesses. According to Weil (2007), the number and severity of H\&S standard violations cited during an inspection provide one measure of the degree to which a contractor's operations comply with OSHA standards.

The level to which contractors' operations comply with OHSA regulatory requirements on construction sites in the Western Cape Region of South Africa were determined by the Master Builders Association Western Cape (MBAWC) for Year 2007, 2008, 2009 and 2010 for annual Safety Competitions using an audit system which was designed by the association for grading the H\&S regulation compliance of construction projects. The Master Builder South Africa Audit Tool (MBSAT) used in the H\&S assessment is classified into 19 different elements and the associated points achievable, each element targeting different requirements of OHSA. While scaffolding, formwork and support accounts for 366 or $19.9 \%$, administrative and legal; cranes; personal, protective equipment and clothing account for 316 or $17.2 \%, 166$ or $9 \%$ and 102 or $5.5 \%$ respectively of the H\&S requirement total points of an achievable 1840 .

The H\&S audit undertaken by MBAWC between 2007 and 2010 when averaged and distributed by compliance to the $19 \mathrm{H} \& S$ requirements revealed that the contractors attained acceptable standards in three elements - cranes, demolition, and transport and material handling; unacceptable standards in eleven elements; and very poor standards in five elements - site plant and machinery workplace environment, health and hygiene, personal protective health and clothing, plant and storage yards, and excavation (See Table 2; Warwick 2011; and MBAWC 2011). While compliance to statutory regulations should mandatorily be set at $100 \%$, the level of contractor compliance was rated by MBSAT based

Windapo, A (2013) 'Relationship between degree of risk, cost and level of compliance to occupational health and safety regulations in construction', Australasian Journal of Construction Economics and Building, 13 (2) 67-82 
on the view that scores above $95 \%$ are seen as acceptable standards, scores between 90 and $95 \%$ can be rated as unacceptable standards which require attention in the short term and below $90 \%$ is rated as very poor standard which require immediate attention (Bester 2011; and Warwick 2011).

\section{Cost of Implementation/Compliance to OHSA Regulations}

Lin and Mills (2001) acknowledge that the higher the investment in safety, the better the performance. According to McGarity and Ruttenberg (1997), the proper measure of the cost of complying with a regulation is the incremental cost above the "baseline" state of the world that would have existed in the absence of the regulations. The real resource cost of compliance according to McGarity and Ruttenberg (1997) consists of three elements: (1) costs associated with the purchase, installation, operation and maintenance of new equipment; (2) changes in the inputs or mixtures used in the production process; and (3) the capture of waste products that can either be disposed of, sold or reused. There are various strategies and systems that have to be put in place for H\&S on construction sites and that have to be paid for by contractors in order to comply with the legislation (cidb 2009a). Smallwood (2004) estimates that the cost of implementing H\&S systems within a construction company lies between $0.5 \%$ and $3 \%$ of total project costs. This study measures the cost of implementing an H\&S system for a project, in line with the estimates provided by Smallwood (2004).

For all but a very few health, safety and environmental regulations, cost according to McGarity and Ruttenburg (2002) is an important consideration because decision makers want to decide whether a given option is 'worth it'. The cidb (2009a) posits that if potential losses relative to labour, materials, plant and equipment as a result of not implementing the requisite preventive measures, are cited, contractors will address H\&S issues.

\section{Safety/Performance Outcome and other Benefits of Compliance to OHSA Regulations}

Occupational Health and Safety (OHS) Regulations impose on enterprises an expected penalty that is positively related to the presence of unsafe working conditions for firms not in compliance with the standards (Viscusi 1979). According to cidb (2009a), the benefits of compliance to the OHSA regulations include reduction in work related illnesses, ergonomics, and more primary health care methods. In addition, cidb (2009a) notes that factors such as increases in insurance premiums, direct costs associated with hospitalization, disability pay, lost workdays and a decrease in productivity are also changing the focus of contractors towards the management of H\&S.

The Cost of Accident (CoA) is the final measure that can readily be related to by all stakeholders as it can be expressed as a percentage of organizational business volume or construction completed, it could also be categorized as being either direct or indirect which collectively constitutes the total CoA and it is noted that in South Africa, the estimated CoA is around $5 \%$ of the value of the completed construction (cidb 2009a). The direct costs of accidents which includes wages and medical expenses tend to be those associated with the treatment of injury and any unique compensation offered to workers as a consequence of being injured and are covered by workmen's compensation insurance premiums. Research by Pillay and Haupt (2008) indicates that direct costs contribute $27 \%$ to the CoA in South Africa. The indirect costs which are borne by the contractors and which are found to contribute $73 \%$ to the CoA according to Pillay and Haupt (2008) include incident investigation costs, production loss, reduced productivity and process delays, the cost of overtime, replacement worker orientation costs, administrative costs, consumables, legal fees, and funeral and compensation due to fatalities. Smallwood (2000) establishes that the indirect costs of accidents are 14.2 times the direct costs.

Windapo, A (2013) 'Relationship between degree of risk, cost and level of compliance to occupational health and safety regulations in construction', Australasian Journal of Construction Economics and Building, 13 (2) 67-82 
This study measures cost savings on construction projects by using the CoA established by cidb as proxy. The study argues that compliance to the OHSA requirements will bring about safe working conditions (Viscusi 1979) and therefore lower costs of accidents $(<5 \%$ of the value of completed construction) on construction projects.

\section{Degree and Level of Risks, which the OHSA Regulatory Requirements attempt to Prevent}

The degree and level of risks which the OHSA regulatory requirements attempt to prevent include: fatal accidents which are caused by contact with moving vehicles; injurie by falling objects; transport; slips/falls on levels; falls from a height; being struck by something; drowning; fire or explosion; and contact with electricity (Dalton 2002; HSE 2004 and Eppenberger 2008). According to the cidb (2009a) report, accident frequency and severity rates are the two essential standards required for reviewing accident statistics. These rates show on average, how often disabling injuries occur in any particular industry; the accident frequency rate; the seriousness of the time loss involved and the accident severity rate. Construction project risks can be evaluated and ranked according to their probability of occurrence and severity of consequence within a project risk matrix (see McGeorge and Zou 2013; and Pinto 2002) as shown in Table 1.

\begin{tabular}{|l|l|l|l|l|}
\hline \multirow{2}{*}{$\begin{array}{l}\text { Potential } \\
\text { Severity of Injury }\end{array}$} & \multicolumn{4}{|c|}{ Probability of Occurrence } \\
\cline { 2 - 5 } & Frequent & Occasional & Remote & Unlikely \\
\hline Catastrophic & Extreme Risk (9) & Extreme Risk (8) & High Risk (7) & High Risk (6) \\
\hline Critical & Extreme Risk (8) & High Risk (7) & Medium Risk (5) & Medium Risk (5) \\
\hline Moderate & High Risk (7) & Medium Risk (5) & Medium Risk (4) & Low Risk (3) \\
\hline Minor & Medium Risk (4) & Low Risk (3) & Low Risk (2) & Low Risk (1) \\
\hline
\end{tabular}

Table 1 Project Risk Matrix After McGeorge and Zou (2013); and Pinto (2002)

The severity rates (SR) indicate to management the seriousness of the disabling injury and the amount of time that will be lost by the worker for every 1,000 hours worked (cidb 2009a). The degree and level of risk (significant risks faced by employees), which the regulatory requirements are trying to prevent/control, will be evaluated in the study in terms of their severity (human capital) and frequency of occurrence by the following classes of accidents (Mthalane et al., 2008):

- Very Severe/catastrophic injuries/fatalities - death results from work injuries on site;

- Severe/major accidents and critical injuries - non-fatal, permanent disablement. These are injuries, which result in amputations or fractures. Injured persons would be absent from work for about 30 days. Major accidents include slips, trips, falling from heights, machinery, transport or electrical accidents;

- Mildly severe/moderate accidents or injuries - non-fatal, temporary disablement; and

- Not severe/minor accidents or injuries - non-casualty, requiring only medical aid. These are accidents, which yield less severe injuries. The absence from work due to this type of injury would usually be two days or less. Most accidents fall into this category - stepping or striking against small objects, tools, sprains or strains.

\section{Research Methods}

The research process used for the study reported started with a literature review According to Yin (1994) the main use of documentation is to corroborate and argue evidence from other sources. In addition, effective design of the research instrument requires a good understanding of the theories underpinning the research area. The research therefore began with a holistic review of the research problems, the OHSA regulations, the degree of risk the

Windapo, A (2013) 'Relationship between degree of risk, cost and level of compliance to occupational health and safety regulations in construction', Australasian Journal of Construction Economics and Building, 13 (2) 67-82 
prescribed regulation requirements attempts to prevent, and cost and benefits of compliance to regulations, in order to understand the variables used in the study. Compliance to regulations and risk prevention and management are areas that have been comprehensively studied and documented in project and construction management, knowledge management, design and technology management, and social studies. The study undertaken is supporting and is aligned to the work of McConnaughey (1978), Weil (2001) and Haupt (2003).

\section{Research Positioning}

The study employs a sequential mixed method research approach, which combines quantitative and qualitative approaches in research design and collection (Abowitz and Toole 2010). The sequential explanatory mixed method involves collection of both quantitative and qualitative data sequentially (Ivankova et al., 2006). The research design allows quantitative data to be collected first and analysed. Second in the sequence is the qualitative (text) data, which are also collected, analysed and used to explain, or expound on the quantitative results obtained in the first place.

Jaselskis (1996) acknowledges that an effective way of measuring the safety performance of a construction company is by using a combination of both qualitative and quantitative measures. While the quantitative approach formulates hypotheses and tests them, the qualitative approach seeks to describe and analyse the behaviour of humans and their groups from the point of view of those being studied (Amaratunga, et al. 2002). Ontologically, the research is premised on an objective view of reality that exists independently and can be uncovered and known through research (Runeson and Skitmore 2008). Following that knowledge is obtained through an understanding of how the degree and level of risk, which the OHSA regulatory requirements attempt to prevent, and the likelihood of its occurrence is constructed through information provided by the respondents. Epistemologically, the research assumes a constructivist paradigm where the nature of knowledge and meaning is a subjective human creation (Baxter and Jack 2008). Quantitative data on the level of compliance to OHSA regulatory requirements was obtained from past records of scores achieved by contractors in the H\&S audit undertaken by MBAWC between 2007 and 2010 using an audit system, which was designed by the association for grading the H\&S regulation compliance of construction projects (see Table 2).

The research methodological stance and positioning adopted a descriptive study approach, which engaged contractors based in the Western Cape province of South Africa between May and September 2011. A combination of convenience and snowball sampling was used to obtain data from 53 contractors who are registered in the MBAWC safety competition and who agreed to participate in the study. In addition, case studies of four construction sites chosen from among those surveyed by the MBAWC for their Occupational Health and Safety site audit were conducted. This allowed for survey data validation and for linking perceptions and costs of OHSA compliance, to the data collected by MBAWC.

The study examined the main sub-clauses of the OHSA legislation that govern H\&S in the South African construction industry. The values for the perceived level of risk and the likelihood of occurrence of the risk which was used in computing the degree of risk, cost of compliance and cost savings shown in Table 2 were measured based on the respondents' rating of the 4-point Likert-scale of Not Severe (1), Mildly Severe (2), Severe (3) and Very Severe (4); and Unlikely (1), Remote (2), Occasional (3), and Frequent (4) respectively. In addition, the cost of compliance and cost savings were measured based on the respondents' rating of a 3-point Likert-scale - Less than $0.5 \%(1)$, Between $0.5 \%$ and $3 \%(2)$, and above $3 \%$ (3) of total project costs; and Low Effect or $<5 \%$ (1), Medium Effect or $5 \%$ (2), and High Effect or $>5 \%$ (3) cost savings on the project.

Windapo, A (2013) 'Relationship between degree of risk, cost and level of compliance to occupational health and safety regulations in construction', Australasian Journal of Construction Economics and Building, 13 (2) 67-82 


\section{Methods of Data Collection and Analysis}

The method of data collection involved a questionnaire survey where the same questions were asked to different respondents (general building contractors) registered in the MBAWC safety competition. This questionnaire survey enabled the consideration of stakeholders who were difficult to reach. In addition, case studies of four construction sites were carried out, involving direct observations and personal interviews. These observations provided useful primary additional information. The questions developed were piloted by way of an interview protocol with three construction industry experts. The pilot study revealed the need to reduce the 19 elements used in the MBSAT audit tool for rating H\&S compliance on construction projects to all the three elements that have acceptable compliance standards; four that have very poor compliance standards minus the plant and storage yard requirement; and two other elements that have the highest achievable points (See Table 3). This was to facilitate the ease of filling in the questionnaires and to improve response rates.

The data collected from the survey and past records on level of compliance maintained by the MBAWC were analysed using frequency analysis, percentage scores, risk matrix analysis (following Table 1), composite risk index (see Ciobanu and Mazilu, n.d), cost of compliance and savings relative importance index, and Pearson Product Moment Correlation and Regression analysis, which was used to test the relationship between the variables.

\section{Test for Reliability}

The study sought to know whether the information supplied by the respondents was reliable. Cronbach's Alpha $(\alpha)$ an index used for objectively measuring the reliability of a questionnaire instrument was used in testing the data collected (Bland and Altman 1997). The acceptable values of $\alpha$ for consistency range between 0.70 and 0.95 (Tavakol and Dennick 2011; DeVellis 2003). The Cronbach's a reliability score of perceived severity of risk, frequency of risk occurrence, direct cost of compliance to OHSA requirements and cost savings due to OHSA compliance investigated is presented in Table 2.

\begin{tabular}{|l|c|c|}
\hline \multicolumn{1}{|c|}{ Perceptions } & $\begin{array}{c}\text { Cronbach } \alpha \\
\text { values }\end{array}$ & No. of Items \\
\hline $\begin{array}{l}\text { Severity of risk that the OHSA requirement attempts to } \\
\text { prevent/control }\end{array}$ & 0.913 & 9 \\
\hline Frequency of occurrence of the risk & 0.920 & 9 \\
\hline Direct cost of compliance to OHSA requirement & 0.859 & 9 \\
\hline Cost savings as a result of OHSA requirement compliance & 0.983 & 19 \\
\hline Overall Cronbach a values & 0.940 & 46 \\
\hline
\end{tabular}

Table 2 Results of Test for Reliability (Cronbach's a values) of Respondents' Perceptions

Table 2 shows that (1) the values of the Cronbach a are greater than 0.85 for each of the respondents' perceptions investigated, based on nine standardized OHSA requirement and (2) the overall Cronbach a value of 0.940 . The results thus suggest that all the perception variables are of high reliability, that there is high interrelatedness between the perceptions, that the research tool developed is reliable because it shows that the respondents genuinely have different opinions and the differences are not because the questionnaire is confusing or has multiple interpretations. 


\section{Results and Discussion}

The data collected from the study conducted will be discussed under the following headings:

\section{Respondents' Distributions and Profiles}

Construction companies surveyed had the following background $-45 \%$ are private liability companies, $38 \%$ are national and international companies, $40 \%$ have been in operation in the construction industry for more than 21 years and $41 \%$ are large companies with more than 100 employees. In addition, $61 \%$ of the respondents are owners or directors of the companies surveyed. The type of business, geographical spread, age and size of the companies surveyed and the status of the respondents indicates that the respondents have the necessary experience and exposure to provide credible and reliable information.

\section{Breakdown of detailed Scores for Variables used in the study}

The detailed breakdown of overall scores for the level of compliance obtained from MBAWC records; relative importance index for cost of compliance and cost savings as a result of compliance (benefits of compliance), probability of accident occurrence and severity of accident; and composite risk index (degree of risk), computed from the data collected through the questionnaire survey and case studies are shown in Table 3 and Figure 2.

\begin{tabular}{|c|c|c|c|c|c|c|}
\hline OHSA Elements & $\begin{array}{l}\text { Level of } \\
\text { Compliance }\end{array}$ & $\mathbf{P I}^{2}$ & $\mathrm{SI}^{3}$ & $\begin{array}{l}\text { Degree } \\
\text { of Risk }\end{array}$ & $\begin{array}{l}\text { Cost of } \\
\text { Compliance } \\
\text { Index }\end{array}$ & $\begin{array}{l}\text { Cost } \\
\text { Savings } \\
\text { Index }\end{array}$ \\
\hline $\begin{array}{l}\text { Cranes (Tower, Mobile } \\
\text { \& Gantry) }\end{array}$ & 0.99 & 0.44 & 0.52 & 0.23 & 0.52 & 0.52 \\
\hline $\begin{array}{l}\text { Demolition Work (Safety } \\
\text { Requirements) }\end{array}$ & 0.97 & 0.49 & 0.53 & 0.26 & 0.58 & 0.54 \\
\hline $\begin{array}{l}\text { Transport \& Material } \\
\text { Handling (safety in use) }\end{array}$ & 0.97 & 0.48 & 0.66 & 0.32 & 0.62 & 0.56 \\
\hline $\begin{array}{l}\text { Admin Structure \& } \\
\text { Legal Requirements for } \\
\text { H\&S }\end{array}$ & 0.94 & 0.46 & 0.79 & 0.36 & 0.63 & 0.53 \\
\hline $\begin{array}{l}\text { Scaffolding, Formwork } \\
\text { \& Support (safety in } \\
\text { use) }\end{array}$ & 0.90 & 0.56 & 0.53 & 0.30 & 0.65 & 0.58 \\
\hline Site Plant \& Machinery & 0.90 & 0.51 & 0.59 & 0.30 & 0.62 & 0.58 \\
\hline $\begin{array}{l}\text { Work Place } \\
\text { Environment Health \& } \\
\text { Hygiene }\end{array}$ & 0.89 & 0.45 & 0.84 & 0.38 & 0.55 & 0.57 \\
\hline $\begin{array}{l}\text { Personal Protective } \\
\text { Health \& Clothing }\end{array}$ & 0.88 & 0.55 & 0.71 & 0.39 & 0.62 & 0.58 \\
\hline $\begin{array}{l}\text { Excavation (adequacy } \\
\text { of side support, etc.) }\end{array}$ & 0.83 & 0.49 & 0.59 & 0.29 & 0.59 & 0.58 \\
\hline
\end{tabular}

Table 3 Breakdown of detailed scores/indices for variables used in the study

${ }^{1}$ Source: MBAWC (2011); 2 Probability of Accident Occurrence Index (PI); 3 Severity Index (SI); and 4 Degree of Risk $=\mathrm{PI} \times \mathrm{SI}$

Table 3 shows that from a ranking perspective, all the OHSA elements considered have fairly equal level of compliance, degree of risk, cost of compliance and cost saving indices. 


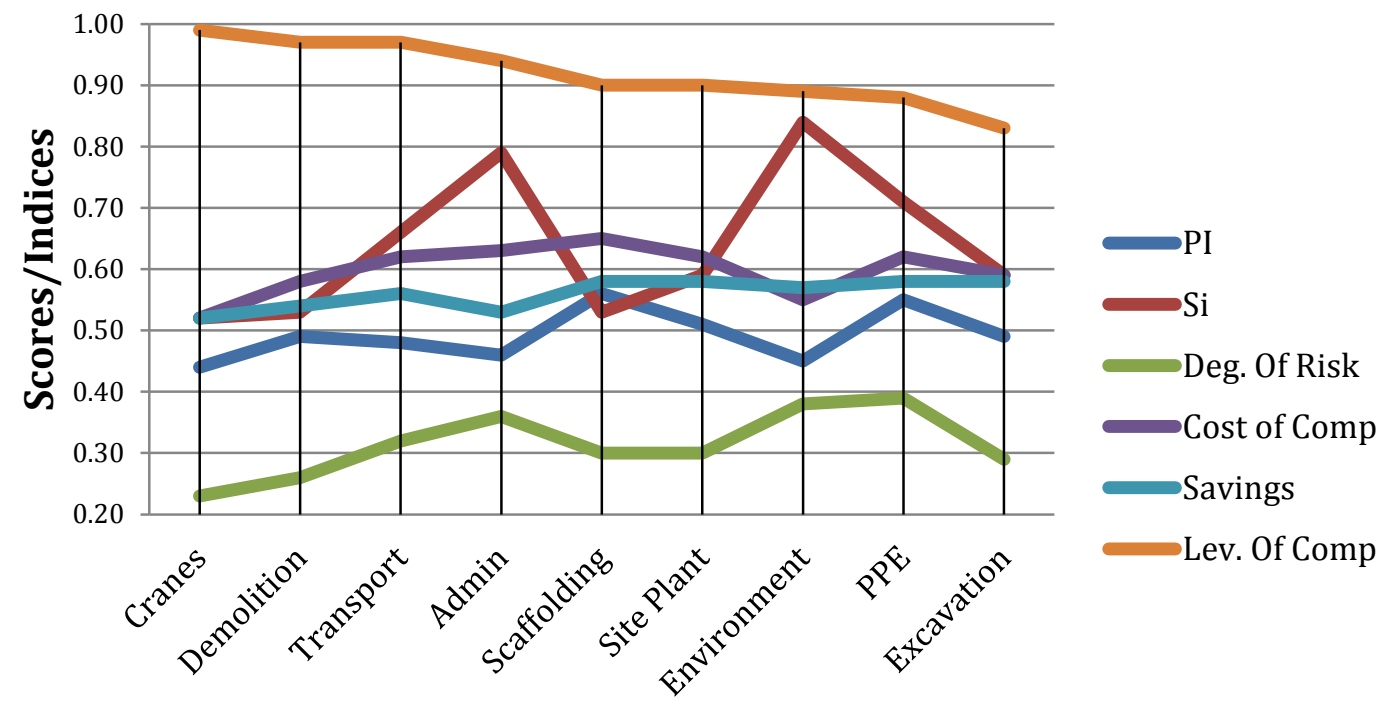

\section{OHSA Elements}

Figure 2 Breakdown of detailed scores/indices for variables used in the study

\section{Relationship between the Degree of Risk, Level of Compliance, Cost of Compliance and Savings}

The correlation coefficients between the degree of risk, overall level of compliance scores achieved for the nine OHSA elements, cost of compliance and savings is shown in Table 4.

\begin{tabular}{|l|r|r|r|r|r|r|}
\hline & $\begin{array}{c}\text { Level of } \\
\text { Compliance }\end{array}$ & \multicolumn{1}{|c|}{ PI } & SI & $\begin{array}{l}\text { Degree } \\
\text { of Risk }\end{array}$ & $\begin{array}{c}\text { Cost of } \\
\text { Compliance }\end{array}$ & $\begin{array}{c}\text { Cost } \\
\text { Savings }\end{array}$ \\
\hline Level of Compliance & 1 & & & & & \\
\hline Probability of accident occurring (PI) & -0.436 & 1 & & & & \\
\hline Severity Index (SI) & -0.224 & -0.284 & 1 & & & \\
\hline Degree of Risk & -0.430 & 0.189 & $0.885^{\star *}$ & 1 & & \\
\hline Cost of Compliance & -0.277 & $0.720^{*}$ & 0.053 & 0.377 & 1 & \\
\hline Cost Savings & $-0.811^{* *}$ & $0.686^{*}$ & 0.075 & 0.406 & 0.474 & 1 \\
\hline
\end{tabular}

Table 4 Correlation Matrix for degree of risk, level of compliance, cost of compliance and savings

${ }^{* *}$ Correlation is significant at the 0.01 level (1-tailed); ${ }^{*}$ Correlation is significant at the 0.05 level (1-tailed)

The results of the study presented in Figure 2 and Table 4 show that the probability of an accident occurring, which is a component of the degree of risk is significantly and positively correlated with the cost of compliance and the perceived cost savings for complying with the OHSA regulatory requirements. This result implies that the higher the probability of a risk event occurring, the more the contractor perceives the direct cost of compliance/implementation and the expected cost savings on accidents to be. The correlation coefficients presented in Table 4 also show a significant but negative relationship between the perceived cost savings on accidents and the level of compliance to OHSA regulatory requirements. This result suggests that the cost savings made by the contractor are perceived to decrease as compliance to OHSA regulatory requirements increases.

Windapo, A (2013) 'Relationship between degree of risk, cost and level of compliance to occupational health and safety regulations in construction', Australasian Journal of Construction Economics and Building, 13 (2) 67-82 
Given the rather poor correlation reported between the other relationships proposed and investigated and shown in Table 4, regression analysis was used to provide a better understanding as to what extent the level of compliance (LoC) to H\&S regulatory requirements is affected by the independent variables of cost of compliance $(\mathrm{CoC})$, degree of risk (DoR) and cost savings (CS). It should be noted however that the purpose of the regression analysis is not for developing a model for predicting a contractor's future level of compliance to $\mathrm{H} \& \mathrm{~S}$ regulatory requirements, but for use in establishing causal relationships between the variables used in the study.

$\mathrm{LoC}=1.845-0.154 \mathrm{DoR}+0.220 \mathrm{CoC}-1.802 \mathrm{CS}$

Table 5 presents the summary of the regression analysis results.

\begin{tabular}{|l|c|c|c|c|c|}
\hline Variables in the model & B & Standard error & Beta & t-stat & Sig \\
\hline constant & 1.845 & 0.312 & & 5.911 & 0.002 \\
\hline Degree of Risk (DoR) & -0.154 & 0.269 & -0.16 & -0.573 & 0.592 \\
\hline $\begin{array}{l}\text { Cost of Compliance } \\
\text { (CoC) }\end{array}$ & 0.220 & 0.361 & 0.177 & 0.61 & 0.568 \\
\hline Cost Savings (CS) & -1.802 & 0.631 & -0.83 & -2.83 & 0.037 \\
\hline \multicolumn{1}{|c|}{$\mathrm{R}^{2}$} & Adjusted R & Standard error of the estimate & $\mathrm{F}$ & Sig \\
\hline 0.832 & 0.693 & 0.58 & 0.03651 & 3.756 & 0.094 \\
\hline
\end{tabular}

Table 5 Regression analysis results for level of compliance (dependent variable), degree of risk, cost of compliance and savings

Table 5 reveals that cost savings make the greatest contribution to level of compliance followed by cost of compliance and degree of risk. Following that a change of one standard deviation on cost savings produces a change of 0.83 standard deviations in the level of compliance, while cost of compliance and degree of risk - neither of which were significant indicate changes of 0.177 and 0.16 respectively. The total variation in the level of compliance is well explained by the independent variables with $R^{2}=0.693$.

This finding suggests that the level of compliance of contractors to H\&S regulatory requirements is responsive to changes in perceived cost savings gained through compliance. Furthermore, the negative correlation coefficient computed between cost savings and level of compliance implies that the cost savings made by the contractor are perceived to decrease as compliance to OHSA regulatory requirements increases. The negative relationship between degree of risk and overall level of compliance indicates that the level of compliance to OHSA regulatory requirements decreases as the degree of risk increases and therefore suggests that the tendency for contractors to comply with OHSA regulatory requirements is not based on the degree of risk which the requirements attempts to prevent or control but on perceived cost savings or loss from non-compliance or compliance respectively. In addition, the positive relationship between the level of compliance and cost of compliance suggests that the level of compliance to $H \& S$ statutory regulatory requirements may increase (all else being equal) with money spent on the implementation of compliance requirements.

\section{Case Study Results}

The results of the questionnaire survey have given some indication of the relationship between the degree of risk, level of compliance, cost of compliance and cost savings. However, four case studies - referred to below as Site A, Site B, Site C and Site D in Table 5

Windapo, A (2013) 'Relationship between degree of risk, cost and level of compliance to occupational health and safety regulations in construction', Australasian Journal of Construction Economics and Building, 13 (2) 67-82 
- were undertaken sequentially within the study sample to reinforce and make the survey findings more meaningful. The type and size of construction projects ranged from housing projects with a budget of less than R20m (Site $C$ and D), to a hospital project of $\mathrm{R} 500 \mathrm{~m}$ budget (Site B) as well as a multi-billion rand power station site (Site A).

\begin{tabular}{|c|c|c|c|c|}
\hline Questions Posed & Site A & Site B & Site C & Site D \\
\hline $\begin{array}{l}\text { Is OHSA implemented } \\
\text { on site? }\end{array}$ & Yes & Yes & Yes & Yes \\
\hline $\begin{array}{l}\text { Level of compliance } \\
\text { with OHSA }\end{array}$ & High & High & High & High \\
\hline $\begin{array}{l}\text { Is the project running } \\
\text { within time? }\end{array}$ & No & No & Yes & No \\
\hline $\begin{array}{l}\text { Is the project running } \\
\text { within budget? }\end{array}$ & No & No & Yes & Yes \\
\hline $\begin{array}{l}\text { Have there been any } \\
\text { reports of accidents/ } \\
\text { injuries? }\end{array}$ & $\begin{array}{c}\text { Yes - Fatalities, } \\
\text { accidents and } \\
\text { injuries }\end{array}$ & $\begin{array}{l}\text { Yes - Accidents } \\
\text { and injuries }\end{array}$ & $\begin{array}{l}\text { Yes - Minor } \\
\text { injuries }\end{array}$ & Yes - Minor injuries \\
\hline $\begin{array}{l}\text { Reasons for non- } \\
\text { compliance }\end{array}$ & $\begin{array}{l}\text { Lack of knowledge; } \\
\text { Cost mitigation - } \\
\text { profit maximisation; } \\
\text { Time consuming }\end{array}$ & Cost mitigation & $\begin{array}{l}\text { Lack of knowledge; } \\
\text { Cost mitigation }\end{array}$ & $\begin{array}{l}\text { Lack of knowledge; } \\
\text { Cost mitigation; } \\
\text { Attitude/negligence }\end{array}$ \\
\hline $\begin{array}{l}\text { Effects of OHSA } \\
\text { compliance on } \\
\text { performance }\end{array}$ & Less accidents & $\begin{array}{l}\text { H\&S is costly but } \\
\text { cost is justified; } \\
\text { overall } \\
\text { performance is } \\
\text { improved }\end{array}$ & $\begin{array}{l}\text { OHSA compliance } \\
\text { is unnecessarily } \\
\text { costly and time } \\
\text { consuming }\end{array}$ & $\begin{array}{l}\text { Quality is improved; } \\
\text { time and cost are } \\
\text { compromised }\end{array}$ \\
\hline $\begin{array}{l}\text { Benefits of complying } \\
\text { with OHSA legislation }\end{array}$ & $\begin{array}{l}\text { Competing on } \\
\text { international } \\
\text { standards; } \\
\text { Penalties \& loss in } \\
\text { production due to } \\
\text { accidents are } \\
\text { avoided; }\end{array}$ & $\begin{array}{l}\text { Increased } \\
\text { productivity }\end{array}$ & $\begin{array}{l}\text { Safe working } \\
\text { environment }\end{array}$ & $\begin{array}{l}\text { Workplace is safe } \\
\text { and thus more } \\
\text { productive; reduces } \\
\text { accidents }\end{array}$ \\
\hline $\begin{array}{l}\text { Any improvements to } \\
\text { existing OHSA } \\
\text { legislation? }\end{array}$ & None & $\begin{array}{l}\text { Adapt to suit } \\
\text { individual project } \\
\text { requirements }\end{array}$ & $\begin{array}{l}\text { Adapt to suit } \\
\text { individual project } \\
\text { requirements }\end{array}$ & $\begin{array}{l}\text { Adapt to suit } \\
\text { individual project } \\
\text { requirements, } \\
\text { which is not } \\
\text { practicable }\end{array}$ \\
\hline
\end{tabular}

Table 6 Summaries of Case Study Interviews

The interviewees were asked questions pertaining to the requirements of the OHSA and the effects they have on level of compliance, accidents, injuries and benefits of compliance. A few project specific questions to establish whether the level of compliance with OHS requirements had an impact on health and safety performance and other performance parameters on a particular site were also examined. The interviewees were then requested to give their opinions on how the regulations in the OHSA Act could be improved. The interview results (Table 6) show that negligent attitudes, lack of knowledge (ignorance) and/or understanding of H\&S regulations by construction site employees and contractors' profit motive are the main causes of non-compliance to $\mathrm{H} \& \mathrm{~S}$ regulatory requirements. This is widely supported by the literature and the survey result analysis. The interviewees believed that non-compliance because of cost mitigation is due to small contractors not including allowances for $\mathrm{H} \& \mathrm{~S}$ requirements in their tenders as a deliberate strategy to win tenders.

Two of the interviewees stated that they did not comply with some of the requirements of the OHSA Act because they perceived them as unnecessarily expensive, time-consuming and unjustified for their particular site (housing projects). They argued that most of the

Windapo, A (2013) 'Relationship between degree of risk, cost and level of compliance to occupational health and safety regulations in construction', Australasian Journal of Construction Economics and Building, 13 (2) 67-82 
requirements of the OHSA regulations are more applicable to larger projects and would be better complied with if they were more project-specific. Other interviewees stated that noncompliance by site operatives could be significantly attributed to negligence/worker attitude, which is a product of risk-taking and each individual's cultural background. In addition to providing a safe work environment, the interviewees stated that compliance with $\mathrm{H} \& \mathrm{~S}$ regulations also gives the firm a competitive advantage. This implies an increased level of compliance with the OHSA requirements is an investment by contractors into the pursuit of corporate growth and profitability.

The interview findings further validate the statistical inference drawn from the analysis of data obtained from the questionnaire and literature survey that the level of compliance by contractors to H\&S regulatory requirements is essentially not influenced by the degree of risk which the H\&S regulatory requirements attempt to prevent, but by perceived cost savings.

\section{Discussion of Findings}

The H\&S regulations in the construction industry were enacted to safeguard lives and to improve the quality of construction products including processes (HSE 2004; Coglianese et al. 2003; and Wolski et al. 2000). However, contractors have been reported to be noncompliant with these regulations (Warwick 2011; Baxendale and Owain 2000; and Coble et al 2000). South Africa is not lacking in terms of H\&S legislation (cidb 2009a) yet, the number of people that get injured or die on construction sites is still high (cidb 2009b; and DoL 2007). Windapo (2011), Bettesworth (2011), MBAWC (2011) and cidb (2009a) attribute factors responsible for injuries and fatalities on construction sites to non-compliance to $\mathrm{H} \& \mathrm{~S}$ statutory regulatory requirements by contractors. This study sought to understand the mindset of contractors and establish whether the decisions made by contractors to comply with $\mathrm{H} \& \mathrm{~S}$ regulations are influenced by the cost of compliance, cost savings and the degree of risk, which the regulation is trying to prevent.

The study established that the level of a contractor's compliance with H\&S regulatory requirements is significantly related to perceived cost savings and unrelated to the degree of risk, which the regulation is trying to prevent. The study findings also reveal that OHSA compliance is considered by contractors to be unnecessarily costly and time consuming to implement and as a result, a contactor perceives that higher level of compliance requires more money. It also emerged in the study that cost savings are positively related with probability of accident occurrence which is a component of the degree of risk. These findings suggest that contractors have a fixation on cost saving where H\&S is involved on projects and that the risk involved in certain construction activities are not given due consideration. This mindset of contractors may not be unconnected with injuries, fatalities and unsafe work conditions reported on construction sites (see Table 6).

According to Viscusi (1979), compliance to OHSA requirements will bring about safe working conditions on construction sites. The study findings are aligned to conclusions made by Emrath (2011) that contractors consider precautions as an unnecessary cost; McGarity and Ruttenburg (2002) that cost is an important consideration in compliance; Williams (1995) that regulatory authorities impose regulations that are in practice unattainable or prohibitively expensive; and McConnaughey (1978) that cost savings derived from the implementation of $\mathrm{H} \& \mathrm{~S}$ regulatory requirements on site are related to the degree of risk which the regulation attempts to prevent - in this study, cost savings were related to probability of accident occurrence.

\section{Conclusion}

Based on the study findings, this paper concludes that the decision made by contractors to comply with H\&S regulatory requirements is influenced by the perceived cost saving on

Windapo, A (2013) 'Relationship between degree of risk, cost and level of compliance to occupational health and safety regulations in construction', Australasian Journal of Construction Economics and Building, 13 (2) 67-82 
account of compliance and that cost savings are influenced by the probability of accident occurrence which is an element of the degree of risk which the regulation is trying to prevent or control (see Figure 1). This paper also concludes that the tendency for a building contractor to comply with statutory H\&S requirements, decreases with increase in cost of compliance, and does not increase with degree of risk or perceived cost savings. The survey results and case studies provided evidence of the profit maximisation motive of the contractors, driven by the competitive nature of the construction industry. In addition, the standards complied with by contractors in the study are not linked with perceived severity of the physical hazards that may occur as a result of non-compliance to H\&S regulatory requirements and estimated degree of risks. This probably explains the fatalities, accidents and injuries that occur on site (see Table 6).

The main implications of the findings to the different stakeholders involved in construction are: non-compliance to H\&S regulatory requirements by contractors because of cost implications will lead to unsafe work condition, injuries and fatalities on construction sites. Contractors will benefit from a safe work environment, reduction in CoA and improved productivity with increased levels of compliance with $\mathrm{H} \& \mathrm{~S}$ regulatory requirements. Although complying with the H\&S regulatory requirements involves upfront costs, the safety and health of construction operatives should take precedence. Secondly these findings suggest that some elements of the H\&S regulations are considered unnecessary, costly and time consuming in implementation by contractors and regulatory authorities should therefore expect issues of non-compliance to $\mathrm{H} \& \mathrm{~S}$ regulations. Thirdly, the study findings imply that accidents will continue to occur on construction sites due to the contractors cost saving mindset, and this should be of concern to both public and private clients.

One possible way to improve compliance would be that, in the same way that provisions are made in tenders for contingencies and insurances, statutory allowances of could be allowed in tenders as part of contract agreements, to enable the implementation of viable $\mathrm{H} \& \mathrm{~S}$ systems by construction companies on site and ultimately the promotion of healthy and safe work environments at the project site. An H\&S consultant could administer these allowances. Future research work can be based on the relationship between the degree of risk, level of compliance with OHSA regulatory requirements, cost of compliance and cost saving, using all nineteen OHSA elements as the basis for analysis, and developing a model which can be used for predicting the likelihood of contractor compliance to statutory H\&S regulatory requirements, based on the parameters of cost of compliance, degree of risk (probability of accident occurrence and severity) and cost savings.

\section{References}

Abowitz, D. and T. Toole (2010) 'Mixed Method Research: Fundamental Issues of Design, Validity, and Reliability in Construction Research', Journal of Construction Engineering and Management, 136, SPECIAL ISSUE: Research Methodologies in Construction Engineering and Management, 108-116

Amaratunga, D. Baldry, D. Sarshar, M. and R. Newton (2002) 'Quantitative and Qualitative Research in the Built Environment: Application of "Mixed" Research Approach', Work Study, 51 (1), 17-31

Ang, G. Groosman, M. and N. Scholten (2005) 'Dutch performance-based approach to building regulations and public procurement', Building Research and Information (March April) 33 (2), 107-119

Ayininuola, G. M. and O. O. Olalusi (2004) 'Assessment of Building Failures in Nigeria: Lagos and Ibadan Case Study', African Journal of Science and Technology, 5 (1), 73-78

Baxter, P. and S. Jack (2008) 'Qualitative Case Study Methodology: Study Design and Implementation for Novice Researchers', The Qualitative Report, 13, 544-559

Windapo, A (2013) 'Relationship between degree of risk, cost and level of compliance to occupational health and safety regulations in construction', Australasian Journal of Construction Economics and Building, 13 (2) 67-82 
Baxendale, T. and J. Owain (2000) 'Construction design and management safety regulations in practice-progress on implementation', International Journal of Project Management, 18 (1), 33-40

Benjamin, P. and J. Greef (1997) Report of the Committee of Inquiry into a National Health and Safety Council in South Africa, Department of Labour, Pretoria

Bester M. D. (2011) Analysis of Occupational Health and Safety Audits Conducted in the Western Cape for period 2007 to 2010, Unpublished Report. Master Builder Association Western Cape, Cape Town

Bettesworth, D. (2011) The compliance debate. [Online] Available at: http://dbtownplanner.co.za/2011/02/21/the-compliance-debate/ [Accessed: 15 April 2011]

Bland, J. and D. Altman (1997) Statistics notes Cronbach's alpha, British Medical Journal, 314, 572

Ciobanu, M. and M. Mazilu (n. d.) 'Environmental Crisis Management through Risk Management', Recent Researches in Tourism and Economic Development, ISBN: 97861804-043-5, 537-541

Coble, R. J. Hinze, J. and T. C. Haupt (2000) Construction Safety and Health Management, Prentice-Hall, New Jersey

Coglianese, C. Nash, J. and T. Olmstead (2003) 'Performance-based regulation: prospects and limitations in health, safety and environmental protection', Administrative Law Review, 55 (4), 705-730

Construction Industry Development Board (cidb) (2009a) Construction Health and Safety in South Africa: Status and Recommendations, cibd, Brooklyn Square, Pretoria. [Online] Available at: www.cibworld.nl/app/export/baPOuCHu/20102760/cidb01.pdf [Accessed 17 January 2010]

cidb (2009b) cidb Construction Industry Indicators Summary Results: 2009, captured by the Construction Industry Development Board in partnership with the Department of Quantity Surveying and Construction Management of the University of the Free State, Available at: http://www.cidb.org.za/knowledge/publications/industry reports [Accessed 4 March 2011]

Dalton, M. (2002) Fatal Accidents in the Irish Construction Industry 1991 - 2001: A Survey of Contributory Factors, Health and Safety Authority Publication, November

De Vellis, R. F. (2003) Scale development: theory and applications, Sage, Thousand Oaks

Department of Labour (DoL) (2007) [Online Resource] Available at: http://www.labour.gov.za [Accessed: 17 October 2009]

Emrath, P. (2011) How Government Regulation Affects the Price of a New Home, National Association of Home Builders, [Online Resource] Available at: HousingEconomics.com, http://www.nbnnews.com/NBN/issues/2011-07-25/ [Accessed 26 July 2011]

Gann, D. M. Wang, Y. and R. Hawkins (1998) 'Do regulations encourage innovation?' Building Research and Information, 26 (5) 280-296

Haupt, T. C. (2003) 'A study of management attitudes to a performance approach to construction worker safety', Journal of Engineering Design and Technology, 1 (1), $42-53$

Health and Safety Executive (HSE) (2004) Improving health and safety in the construction industry, The Stationery Office, London

Eppenberger, M. (2008) Older construction workers: a study of related injuries, underlying causes and estimated costs, Unpublished Masters Theses, Cape Peninsular University of Technology, South Africa

Ivankova, N. V. Creswell, J. W. and S. L. Stick (2006) 'Using mixed methods sequential explanatory design: From theory to practice', Field Methods, 18 (1), 3-20

Windapo, A (2013) 'Relationship between degree of risk, cost and level of compliance to occupational health and safety regulations in construction', Australasian Journal of Construction Economics and Building, 13 (2) 67-82 
Jaselskis E. (1996) Strategies for achieving excellence in construction safety performance, Journal of Construction Engineering and Management, 122 (1), 61-70

Lin, J. and A. Mills (2001) Measuring the occupational health and safety performance of construction companies in Australia, Facilities, 19 (3/4), 131-138

Master Builders Association Western Cape (MBAWC) (2011) Construction Occupational Health Safety Environment Regional/National Competition Audit System and Star Grading Program, MBAWC, Cape Town

McConnaughey, J. S. (1978) An Economic Analysis of Building Code Impact: A Suggested Approach, National Bureau of Standards, NBSIR 78 - 1528, Washington, DC

McGarity, T. O. and R. Ruttenberg (2001-2002), 'Counting the Cost of Health, Safety and Environmental Regulation', Texas Law Review, 80, 1997-2058, downloaded from http://heinonline.org [Accessed 17 June 2010]

Mthalane, D. Othman, A. A. and R. G. Pearl (2008) The economic and social impacts of site accidents on the South African society, School of Civil Engineering, Surveying and Construction, Faculty of Engineering, University of KwaZulu-Natal, Durban, South Africa

McGeorge, D. and P. Zou (2013) Construction Management: New Directions, $3^{\text {rd }}$ Ed., WileyBlackwell, United Kingdom

Odeyinka, H. Larkin, K. Cunningham, G. McKane, M. Bogle, G. and R. Weatherup (2011) 'Development of models for assessing risk impacts on the variability between contract sum and final account', Proceedings $27^{\text {th }}$ Annual ARCOM Conference, 12-13 September, School of the Built Environment, University of Salford, London, 614-623

Pillay, K. and T. C. Haupt (2008) 'The Cost of Construction Accidents: A Pragmatic Study', Proceedings of the $3^{\text {rd }}$ Build Environment Conference, T. C. Haupt (ed), Cape Town, 6-8 July, 268-283

Pinto, J. K. (2002) 'Project management 2002', Research-Technology Management, 45 (2), 22-37

Runeson, G. and M. Skitmore (2008) 'Scientific Theories', in Knight, A. and Ruddock, L. (eds), Advanced Research Methods in the Built Environment, Wiley-Blackwell, United Kingdom, 75-85

Sidumedi, K S. (2009) 'An investigation into the Relationship between the corporate culture of South African construction firms and performance' [Online], Available at: http://wiredspace.wits.ac.za/handle/10539/7942[Accessed: 28 June 2011]

Smallwood, J. J. (2000) A study of the Relationship between Occupational Health and Safety, Labour Productivity and Quality in the South African Construction Industry, Unpublished PhD Thesis, Department of Construction Management, University of Port Elizabeth, Port Elizabeth

Smallwood, J. (2004) 'The influence of engineering designers on health and safety during construction', Journal of the South African Institution of Civil Engineering, 46 (1), 217-226

Spence, R. (2004) 'Risk and regulation: can improved government action reduce the impact of natural disasters?' Building Research and Information, 32 (5), 391-402

Stigler, G. (1971) 'The Theory of Economic Regulation', Bell. Journal of Economics and Management Science, 2, 3-21

Tavakol, M. and R. Dennick (2011) 'Editorial: Making sense of Cronbach's alpha', International Journal of Medical Education, 2, 53-55

Ulang, N.M. Gibb, A.G.F. and C.J. Anumba (2010) 'The communication of health and safety information in construction', Proceedings of CIB World Congress, [CIB W099 Special Track], 1 May 2010, Manchester

Windapo, A (2013) 'Relationship between degree of risk, cost and level of compliance to occupational health and safety regulations in construction', Australasian Journal of Construction Economics and Building, 13 (2) 67-82 
van Huyssteen, S. van Heerden, L. Perkins, P. and O. Gyimah (2002) 'The identification and measurement of performance indicators for the South African construction industry', [Online], Available at: http://buildnet.csir.co.za/cdcproc/docs/3rd/vanhuyssteen\%20 vanheerden.pdf [Accessed: 28 June 2011]

Viscusi, W. K. (1979) 'The Impact of Occupational Safety and Health Regulation', The Bell Journal of Economics, 10 (1), 117-140, downloaded from http://www.jstor.org/stable/3003322 [Accessed 17 June 2010]

Warwick, J. (2011) 'Building industry safety needs to be of stellar standard' [Online].

Available at: http://www.crown.co.za/news/2011/July/building industry safety needs to be of stellar st andard.htm [Accessed: 23 July 2011]

Weil, D. (2001) 'Assessing OSHA Performance: New Evidence from the Construction Industry', Journal of Policy Analysis and Management, 20 (4), 651-674, downloaded from: http://www.jstor.org/stable/3325777 [Accessed 17 June 2010]

Williams, P. (1995) 'A regulation evaluation system: a decision support system for the Building Code of Australia', Construction Management and Economics, 13, 197-208

Winch, G., and E. Campagnac (1995) 'The Organization of Building Projects: an Anglo/French Comparison', Construction Management and Economics 13, 3-14

Windapo, A. O. (2011) 'Investigation into the Level of Compliance to Construction Health and Safety Requirements within the South African Construction Industry', Proceedings of the ClB W099 Conference, 23-25 August, Washington D. C

Wolski, A. Dembsey, A. N. and B. J. Meacham (2000) 'Accommodating the perceptions of risk in performance-based building fire safety code development', Fire Safety Journal, 34, 297-309

Yin, R. K. (1994) Case Study Research: Design and Methods, 2nd Ed., Sage Publications, London 